\title{
INTRODUCTION
}

\section{A Biographical Sketch}

The year was 1905 . At a medical school in Japan a twenty-fouryear-old Chinese student stalked angrily out of a lecture hall and decided to abandon his medical training then and there in order to devote himself entirely to literature. That student was Lu Xun (I88I-1936), who was to become one of the modern world's greatest writers. ${ }^{1}$

During the mid-nineteenth century Western traders and missionaries had flocked to China and Japan in search of easy profits and heathen souls. As the century drew to a close, China remained helpless before this alien tide while Japan, long since gripped by the urgent need to modernize, had begun to turn it back. So successful was China's eastern neighbor in this regard that in 1894, apparently emulating the rapacious greed of the Western powers, she declared war on China. In the treaty that ended the fighting one year later, Japan won control of Taiwan and the Pescadores, and also the right to open trade in seven Chinese ports.

Suddenly it was clear that, like it or not, China would have to modernize in order to survive. Once the need for modernization had been recognized, the next logical step was to send large numbers of students to study in Japan; closer by far than either Europe or America, Japan also relied on a language that was easier for most Chinese to acquire and use than any Western tongue. Of still greater significance, however, was the fact that Japan, an Asian nation, had been demonstrably successful in penetrating the secrets of Western wealth and power.

$\mathrm{Lu}$ Xun was one of those students dispatched to Japan in the wake of Japanese victory. Graduating from the government-sponsored School of Mines and Railroads in Nanjing during the winter of 190I, he arrived in Tokyo the following spring and was for the next two years a student at the Kōbun Academy. This school had been established by the Japanese government especially to teach overseas Chinese students the Japanese language skills they would need to enter institutions of higher learning in Japan.

I. Lu Xun is the pen name of Zhou Shuren. 
While in Tokyo Lu Xun wrote articles and published them in overseas Chinese student journals, introducing various fields of modern science to his compatriots and simultaneously exhorting them to patriotism. He also found time to translate two Jules Verne novels into Chinese: From the Earth to the Moon and Voyage to the Center of the Earth. Making full use of the Japanese translations, $\mathrm{Lu}$ Xun brought these works of science fiction over into Chinese in order, as he grandly announced in the preface to one of them, "to sweep away inherited superstitions, improve thought, and aid the cause of civilization." As a young member of the up-and-coming intellectual elite, he was confident that he knew not only what ailed China (the backward, superstitious thinking of her people) but also what was wanted in the way of a cure (popularization of scientific thought). Within the next few years, however, he would come to reject this judgment.

Upon graduation in 1904, young Lu Xun left Tokyo for Sendai to attend medical school. He could well have picked a school closer to hand, in Tokyo proper perhaps, or across the bay at Chiba. Intense dissatisfaction with the majority of his fellow Chinese students, however, made him decide to get as far away from them as possible. In Lu Xun's eyes these students were at once frivolous, mindlessly adopting the outer trappings of Western civilization (mainly social customs such as ballroom dancing), and cynically practical, pretending to pursue their studies in order to "save China" while their actual motives were to earn high salaries in prestigious positions after graduation. Lu Xun would have none of this. Instead he went to Sendai, where he would be the only Chinese student.

Located in Miyagi prefecture about two hundred miles north of Tokyo, Sendai was something of a military town as well as a university one. The Second Division of the Japanese army reserves was stationed there. When Japan took up arms against Russia in I904, the Second was immediately called up and dispatched to Manchuria. Hundreds of Russian prisoners were taken in Manchuria and sent back to Sendai, where their captured army capes came to be much prized among the local citizenry, who were imbued with a heady blend of patriotic jingoism and hometown pride.

These were not the best of times to be the only Chinese student in the town of Sendai. Though the Sino-Japanese War was now a 
full decade behind, an atmosphere of arrogance still lingered here: Chinese were often contemptuously referred to as chanchan bozu (roughly equivalent to "Chinks" in English).

Lu Xun's instructor in microbiology used a slide projector to introduce the various microbes to his students. If the lesson finished early, he would use the remaining time to show slides of natural scenery-or scenes of the war. On one such occasion, as his fellow students shouted one wall-shaking Banzai! after another, $\mathrm{Lu}$ Xun looked at a slide showing a Chinese on the verge of decapitation at the hands of Japanese military men in Manchuria. According to the caption, this man had been caught spying for the Russians. Lu Xun was not so much interested in the condemned "spy" as he was in the Chinese bystanders, shown gathered round to watch the execution. Though they appeared physically sound and in no need of medical care, he inferred from their facial expressions that, psychologically, they too were close to death. Suddenly realizing that China needed someone to doctor its people's spirits more than someone to look after their physical health, he strode out of the lecture hall that day and decided to devote himself to the creation of a literature that would minister to the ailing Chinese psyche.

Lu Xun returned to Tokyo in the spring, determined to spark a spiritual revolution through the written word. Although to outsiders such a melodramatic step may appear quixotic, one should remember that Confucian ideology, a tradition in which Lu Xun had himself been schooled, was preeminently an affair of books, of canonical texts endlessly memorized and commented upon in order to assure the moral authority and intellectual orthodoxy of the scholar-officials who ruled the land. Moreover, these officials ruled primarily through the power of the written word, whose magical force was assumed by those whose lives it regulated. Against this background, Lu Xun's melodramatic decision takes on a more practical meaning.

But in the summer of 1906 something happened that remains difficult to explain even today, something that has so puzzled Lu Xun's biographers as to tempt them to ignore or even suppress it. At his mother's behest and showing uncharacteristic passivity, Lu Xun returned to Shaoxing and submitted to a parentally arranged marriage with a certain Zhu An, a marriage that is said to have never been consummated. In effect, Zhu An spent the rest of her 
life living in the Zhou household as a "grass widow" whose main function was to wait upon her mother-in-law.

In the fall of 1906 , not long after his marriage, Lu Xun returned to Tokyo with his younger brother, Zhou Zuoren (r885-1968). ${ }^{2}$ Zuoren had won a government scholarship and was to remain in Japan until I9II. While there he would fall utterly under the spell of Japanese culture and would choose a Japanese woman, Habuto Nobuko, as his wife. Perhaps Zuoren enjoyed more freedom in his choice of a mate than did his elder brother, for in traditional China responsibility weighed most heavily on the shoulders of the eldest male. This background may be particularly salient in the case of Lu Xun's family, since his father, a man stalled in mid-career by alcohol and opium, had died in 1896 of a protracted illness that Chinese doctors had proved helpless to treat. Indeed, the circumstances surrounding his father's death had been one of the factors leading Lu Xun to study Western medicine in the first place.

During 1907, amid a flurry of other activities, the two brothers joined with another young man from their native Zhejiang Province, Qian Xuantong (1887-1939), ${ }^{3}$ and a few others to organize a Society for the Promotion of National Learning. They invited the renowned scholar and highly respected anti-Manchu revolutionary Zhang Taiyan (I868-1936) to serve as director of their group and to lecture them on Chinese literature and philology. A political activist, Zhang had earlier broken with the constitutional monarchists $^{4}$ and had turned to openly advocating revolution. The Manchu government had jailed him in Shanghai between 1903 and 1906 for activities that were deemed "seditious." Arriving in Japan after his release, Zhang was a ready-made hero among the Chinese student population of Tokyo. This patriotic and highly individualistic scholar exercised considerable influence on Lu Xun.

In keeping with his resolve to use literature to minister to the ailing Chinese psyche, Lu Xun now banded together with a number of his like-minded countrymen in an attempt to launch a new literary movement. Their first visible step was to organize publication of a magazine entitled New Life. As the proposed date of their

2. Lu Xun, it will be remembered, was the pen name of Zhou Shuren.

3. His son Qian Sanqiang (b. 1913), a nuclear physicist, was instrumental in the development of China's atomic bomb.

4. This was the group that had advocated modernizing China while retaining the imperial system of government, a program that echoed the Japanese model. 
inaugural issue approached, however, manuscripts and funds that had been promised in support of the new venture failed to materialize and the enterprise was abandoned.

$\mathrm{Lu}$ Xun later brought out a number of the articles he had prepared for the stillborn New Life in the magazine Henan, published in Japan by the association of overseas Chinese students from that province. One essay, entitled "On Breaking Through the Voices of Evil," revealed how drastically his thinking had changed since the time of his earlier stay in Tokyo. Far from blaming China's backwardness on the "inherited superstitions" of the common people, he now appeared to turn against members of his own class, asserting that the accusation of superstition was only a convenient slogan of hypocritical gentry scholars who hoped to absolve themselves of responsibility for the current national crisis by laying the blame for China's unfortunate plight at the doorstep of the common people.

In another essay, "The Power of Mara Poetry," Lu Xun called upon his fellow countrymen to become "warriors of the spirit," writers who would give voice to the sufferings of China's silent masses and articulate their hopes and fears, writers who would, at the same time, exhort the whole Chinese people to reform their society and stir them to resist oppression. Of the many foreign writers whom Lu Xun identified as warriors of the spirit (his term for all such writers was "Mara Poets"), he singled out Nikolai Gogol (1809-1852) for special praise: "His was a voice," Lu Xun remarks, "that broke a Russian silence of centuries, making the world aware of the hitherto invisible traces of tears on the tragic faces of a suffering people." We might observe in this light that Lu Xun's first colloquial short story, "Diary of a Madman," was inspired by Gogol's story of the same name; and when Lu Xun died in 1936, he was still at work on the second volume of his translation of Gogol's novel Dead Souls.

As he had done in earlier days there, Lu Xun continued to translate in Tokyo, pursuing what was to be his lifelong passion. But now, rather than the science fiction of Jules Verne, he worked on the stories of Leonid Andreyev (1871-1919) and Vsevolod Garshin (I855-I888). He combed the world literature that was available to

5. Lu Xun glossed the name Mara as meaning "devil," claiming that this epithet was first applied as such to the English romantic poet Byron. 
him in Japanese and German - the only two languages, other than Chinese, he knew well enough to read easily-for stories created by authors from weak and oppressed nations that shared, he felt, the fate of his own homeland. For Lu Xun, the function of the translator was not less important than that of the creative writer. ${ }^{6}$

In an essay entitled "The Erratic Development of Culture," young Lu Xun argued that China's weaknesses and strengths all proceeded from the same cause-isolation. Because of her distance from the other centers of world culture, China had seldom been the target of cultural stimulation from abroad and the result, $\mathrm{Lu}$ Xun felt, had been gradual atrophy. Just as the creative writer could break through internal barriers of silence and give voice to the sufferings of common people, so might the translator break through external barriers of language and culture separating one nation from another.

Lu Xun's first efforts to tear down the cultural walls that cut China off from the world at large resulted in a two-volume collection of short stories, Tales from Abroad, consisting of works translated by himself and his brother and published jointly under this title in 1909. The production cost was defrayed by a Chinese banker who had traveled to Tokyo for an ear operation. His contribution paid for printing one thousand copies of volume one and five hundred of volume two, which were marketed in both Tokyo and Shanghai. We have no record of the Shanghai sales, but in Tokyo only twenty-one copies of the first volume and twenty of the second were ever bought. Lu Xun and his brother were plainly ahead of their time. The political revolution that would destroy the Manchu dynasty was only two years away, but the literary revolution, for which the two brothers were so well prepared, was to be a decade in the making, and the evidence of its beginning was still invisible to them.

Lu Xun might have stayed longer in Tokyo this time, despite the failure of Tales from Abroad, but in the end it was lack of money that drove him home. Not only did the family back in Shaoxing need his financial support, but Zuoren's family in Tokyo needed it too. On the surface, it almost appears that Lu Xun sacrificed his own interests to those of his younger brother, much as he had done a few years earlier for the sake of his mother when he mar-

6. Lu Xun's collected translations run to ten volumes. 
ried Zhu An. In any case, he now returned to China in 1909 to assume a teaching position at the Zhejiang Bi-level Normal School in Hangzhou. ${ }^{7}$ This job had been arranged for him by his fellow townsman and lifelong friend Xu Shoushang (1882-1948), who had just returned from Japan the previous year and was now dean of studies at the school. ${ }^{8}$

Upon landing in Shanghai and before proceeding to his teaching post in Hangzhou, the twenty-eight-year-old Lu Xun bought an artificial queue from a store that specialized in their sale to Chinese students returning from abroad. ${ }^{9}$ To all but the most discerning eye, these fake queues were indistinguishable from the real thing. Nonetheless, Lu Xun gave up wearing his after only a month, because it occurred to him that to have the thing fall off unexpectedly or-worse yet-to have someone pull it off would be far more embarrassing than to appear without it.

Situated in the provincial capital of Lu Xun's native Zhejiang, the Zhejiang Bi-level Normal School had originally been an examination hall. When the Confucian civil service examinations were abolished in 1905 , it had been rebuilt as a normal school patterned after a similar institution in Tokyo, and Japanese nationals had been engaged to teach some of the courses. Since many of the Japanese did not speak Chinese, classroom interpreters were needed. Aside from teaching one course in chemistry and one in physiology, $\mathrm{Lu}$ Xun also served as interpreter for the Japanese instructor of botany. In this capacity he was required to translate the lecture sentence by sentence and then to interpret between instructor and students during a question-and-answer period following the lecture.

The Japanese presence weighed heavily in Hangzhou, one of the ports Japan had forced open to trade under the treaty ending the

7. The school trained both primary and secondary school teachers, hence the term bilevel.

8. A native of Shaoxing, Xu was finally assassinated in 1948 by a Kuomintang (Nationalist Party) agent in Taibei because of his leftist sympathies, and also because he had tried to popularize Lu Xun's works among students at National Taiwan University.

9. After their conquest of China in 1644, the Manchus required Chinese males to adopt their alien coiffure, which involved shaving the front of the head while letting the hair grow long at the back and braiding this into a queue; cutting off the queue came to be considered a gesture of defiance against the Manchu regime. The government did, however, make some allowance for returning students since, it was thought, they might have cut off their queues while abroad simply in order to blend with the local population. 
Sino-Japanese War (1894-95) more than a decade earlier. Just as the Western powers had done before her, Japan established enclaves of immunity within the treaty ports where foreigners were beyond the reach of Chinese law. In Hangzhou the Gonghuan Bridge and environs on the north side of town became such an enclave. Among the attractions of this area was a house of prostitution that some of Lu Xun's colleagues liked to frequent on weekends. Lu Xun is known to have admonished his colleagues on one occasion: "Gonghuan Bridge is a piece of Chinese territory occupied by the Japanese. It's Chinese women who are being violated in the brothel there. Isn't that shameful enough? Of all places, why do you have to go there to take your pleasure?"10

The twin afflictions plaguing all of China at this time were thus plainly evident in Hangzhou. While the Japanese of the Gonghuan Bridge area gave meaning to the word imperialism, the administration of the normal school fleshed out the concept of feudalism. ${ }^{11}$ During Lu Xun's second year of teaching there, a conservative Confucian ideologue was appointed as new director of the school. He insisted that the dean of studies, Xu Shoushang, perform a ceremonial kowtow in honor of Confucius. Xu refused and resigned from the school in protest. Then one after another, the faculty, Lu Xun among them, tendered their resignations in support of their dean. Eventually the new director was himself forced to resign, while the former faculty were all reinstated.

Then in r9ro Lu Xun accepted a position as instructor and dean of studies at the Shaoxing High School. Traditional Chinese schools taught the Confucian classics and prepared their pupils to sit for the civil service examinations. Modern schools like the Shaoxing High School, on the other hand, taught both the classics and contemporary subjects such as natural sciences and foreign languages. Upon graduation from one of these schools a student could either move to an institution of higher learning and pursue, say, engineering or (until r905) sit for the civil service examinations. Modern schools were also likely to be centers of revolutionary political activity, and those in Shaoxing were no exception. The Shaoxing High School had been established in 1897 as a grass-

\footnotetext{
I0. See Lin Zhihao, Lu Xun Zhuan (A Biography of Lu Xun) (Beijing: Beijing Publishing Co.), p. 62 .

Ir. The term feudalism here refers to the traditional Chinese society, following the usage now standard in the People's Republic of China.
} 
roots effort at modernization by a certain retired government official, with the explicit objective of producing large numbers of "ideal citizens" trained equally in morals, intellect, and physical cultivation. When the school had first opened its doors to students in 1899, Cai Yuanpei ( $1868-1940$ ), another of Lu Xun's lifelong friends and fellow townsmen, had been its first principal. ${ }^{12}$

In I90I the revolutionary martyr Xu Xilin (1873-1907) had been engaged by the school to teach the Confucian classics and mathematics. Also a native of Shaoxing, $\mathrm{Xu}$ had been promoted to assistant principal by 1903 . In 1905 he left with a large contingent of his students ("disciples" would perhaps be a better word) for Japan, where they were ostensibly to study under his guidance. While in Japan, however, they spent most of their time planning and organizing for the revolution at home. Upon returning to China Xu found a position as head of the Anhui Police Academy. When the governor of the province came to participate in the academy's graduation ceremony, $\mathrm{Xu}$ assassinated him in hopes this would be the spark to set off the revolution at last. Following his violent act, $\mathrm{Xu}$ and some of his students entered and occupied the police armory, managing for a while to hold off the governor's troops. Later the same day, however, they were all captured. The governor's bodyguards cut out Xu Xilin's heart, then fried and ate it along with his liver to give scope to their fury and demonstrate their loyalty to the dead governor. Later, the grisly circumstances surrounding Xu Xilin's death would find their way into the tenth entry of Lu Xun's first colloquial short story, "Diary of a Madman."

In a related intrigue, a female cousin of Xu's, Qiu Jin (b. 1879), took charge of the Datong Academy for girls in Shaoxing during 1907, having planned a coordinated uprising jointly with $\mathrm{Xu}$ so that while he was taking over Anhui Province, she was supposed to take control of Zhejiang. Shortly after Xu's execution, however, she was betrayed by an informer in Shaoxing and soon arrested; the local Manchu government officials subsequently dis-

12. Also a native of Shaoxing, Cai had received a traditional education and had won the highest degrees attainable within the civil service examination system by the time he was twenty-two. Despite his outstanding academic record and his bright prospects for an official career, Cai became a revolutionary. In 1902, along with Zhang Taiyan, he became a founding member of the China Education Society, a revolutionary group dedicated to overthrowing the Manchu regime. 
covered that Qiu Jin had secretly commandeered almost fifty guns and more than six thousand rounds of ammunition. She was publicly executed in central Shaoxing two days after her arrest. ${ }^{13}$

Thus it was little wonder that the government distrusted the new schools. Teachers who had studied abroad, where they might have been tainted by revolutionary sentiments or even have joined one of the revolutionary secret societies, were especially vulnerable to suspicion. So when Lu Xun moved to the Shaoxing High School as instructor and dean of studies in I9Io, the local Manchu magistrate kept a close eye on him. Every one of the thirty-two faculty members at the school, with the sole exception of Lu Xun, wore traditional Chinese dress (long gown and mandarin jacket) and made a show of the obligatory queue (whether real or counterfeit). Lu Xun, on the other hand, dressed himself in Western clothes, sported a moustache, and went scandalously bareheaded.

Years later Lu Xun would recall that the situation in Shaoxing had been even worse than the one he left in Hangzhou. In Hangzhou, at least, he had occasionally been able to pass as a "foreign devil," one of the many Japanese nationals that populated the city, but back in his own hometown, such anonymity was impossible. Some people cursed him as "a Chinese sellout to the foreign devils," while others opined that he probably had lost his queue as punishment for some crime-perhaps for making off with a girl from a respectable family. ${ }^{14}$

Among the students of the Shaoxing High School, Lu Xun earned the reputation of being inconsistent when he opposed some of them who threatened to cut off their queues too. He reasoned that although the government might make allowances in his own case (since he had studied overseas), it would be very unlikely to tolerate such activity among students. When the students went ahead with the plan and cut their queues anyway, however, Lu Xun staunchly defended them and even managed to protect them from punishment by either school or government officials.

\footnotetext{
13. In Lu Xun's story "Medicine," a young revolutionary is executed at "Old Pavilion Road Intersection" the real place, in fact, where Qiu Jin met her death. Today a monument stands close to this spot in Shaoxing.

I4. One of the characters in Lu Xun's best-known short story, "Ah Q-The Real Story," is openly reviled on the street and nicknamed "Fake Foreign Devil" because of his absent queue.
} 
When news of the Republican Revolution reached Shaoxing in October of I9II, most people in town, not knowing what to expect, were on the edge of panic. In this charged atmosphere $\mathrm{Lu}$ Xun emerged as a natural leader who did his best to restore calm and to educate people about the significance of current events. After Republican forces liberated Shaoxing and established the new military government, Lu Xun was appointed principal of the Shan-Kuai Primary Level Normal School. ${ }^{15}$

Like almost everyone else, Lu Xun had cherished extravagant hopes for the Revolution. Before long, however, the new "revolutionary" government at Shaoxing itself began to show signs of corruption, taking little visible interest in any governmental functions except the collection of taxes. Thus, when offered a position in the newly formed Ministry of Education at Nanjing, Lu Xun left Shaoxing in February of 1912 with few regrets. ${ }^{16}$ He would follow the ministry northward to Beijing when the capital was shifted there a few months later.

Late in I9II but before leaving his hometown, Lu Xun wrote his first short story, "Remembrances of the Past." Though written in the literary Chinese idiom, this story is modern in most respects and presents a view of reality consistent with that found in the twenty-five stories he would later write in the colloquial language between 1918 and 1925. But the fame enjoyed by Lu Xun's later colloquial stories has generally eclipsed the merits of this first literary experiment.

After "Remembrances of the Past," Lu Xun would not write another work of fiction until I9r8, marking a literary hiatus that coincided with a dark period of political and cultural stagnation within the Chinese nation as a whole.

Not long after the Revolution, Sun Yat-sen, idealistic founder and first president of the republic, had ceded his position to Yuan Shikai (1859-1916). A high-ranking official and military man under the Manchu dynasty, Yuan had commanded enough military strength to complete and consolidate the overthrow of the old imperial regime. Recognizing the political reality that his power

I5. Before the victory of the Chinese Republic, the two halves of Shaoxing, lying to the east and west of a line bisecting the city from north to south, had belonged to two different counties, Shanyin and Kuaiji. The school was named for these two counties.

16. Cai Yuanpei, then minister of education, made the offer to Lu Xun through his friend Xu Shoushang (see n. 8). 
represented, Sun Yat-sen and the revolutionaries had yielded to him the presidency of their infant republic.

Through his autocratic administration, Yuan soon made it plain that he had little use for the democratic ideals held by the revolutionaries. They in turn were disenchanted with their president and in 19r3 attempted to launch a "second revolution" from the provinces, hoping to overthrow him. They failed and Sun was forced to flee to Japan. Thereafter, President Yuan increasingly ignored the important principles upon which the republic had been founded and finally, in 1915, he declared himself to be emperor of a new dynasty. Disaffection in the provinces and his own death one year later closed the curtain on this farcical imperial revival. But the republic could only limp along toward warlordism and chaos thereafter.

In May of I9I2 the new Ministry of Education moved to Beijing, where it was housed in what had been the premises of the old Imperial Board of Education. Indeed, some of the same personnel (under new republican titles) were carried over along with the buildings. With the vice-minister as their leader, this group of the old guard formed a powerful conservative faction against which the progressive new minister, Cai Yuanpei, only fought in vain. Like Sun, he too was quickly forced out of office. Thereafter the Ministry of Education settled down into a dull round of bureaucratic days.

But for Lu Xun, the year 1916 brought the brief diversion of an exciting family drama whose events would later provide material for his first story in the colloquial language, "Diary of a Madman." A certain maternal cousin of Lu Xun's arrived in the capital utterly convinced that he was pursued by deadly enemies. Once established in a hotel, he proceeded then to move around in it from one room to another, supposedly in an attempt to evade his persecutors. Eventually Lu Xun offered his cousin shelter in his own quarters. One morning, in a state of apparent panic, the cousin announced that he was going to be decapitated that very day, entrusting Lu Xun with a farewell letter addressed to his family. At this juncture $\mathrm{Lu}$ Xun packed his cousin off to a hospital, but when he showed no signs of improvement there was no choice but to arrange for someone to take him back home to Shaoxing.

Soon after Yuan Shikai's death in 1916, the new president of the republic, Li Yuanhong, was at loggerheads with the powerful 
northern warlord Duan Qirui (1867-1936). In the summer of 1917, President Li foolishly invited the military governor of Anhui Province, Zhang Xun (1867-1943), to proceed toward Beijing and support him against Duan. In the event, Governor Zhang was only too willing to respond. An ultraconservative man who, along with all his troops, had retained his traditional Manchu hairstyle, Zhang promptly marched into the capital and declared a restoration of the imperial monarchy. Duan Qirui then led a coalition of warlords against Zhang, defeated him, and forced Li Yuanhong to resign from the presidency. In his place a puppet president was installed. Eventually this whole sequence of events provided the background for Lu Xun's creation of the story "A Passing Storm."

At about this time, in August of 1917, Qian Xuantong began to come visiting. He urged Lu Xun to contribute a piece to New Youth, the journal then being published by another group of young intellectuals also attempting to spark a revolution in Chinese culture. Lu Xun's contribution to the magazine turned out to be "Diary of a Madman," the first truly modern short story-modern in content, structure, and language-in the Chinese literature of the period.

The story opens innocuously with a short introduction written in classical Chinese, explaining the origin of the diary entries that follow and assuring the reader that the madman author who penned them has now recovered. Proof of his recovery is claimed to lie in the fact that he has again taken his accustomed place within the official governing bureaucracy. The literary language of this introduction establishes a somber and impersonal tone, against which the colloquial language of the diary entries stand out in stark contrast. Through the fictional diarist Lu Xun delivers a withering attack on traditional Chinese society, portraying it as a cannibalistic feast with strong characters literally devouring weak ones while hypocritically cloaking their own barbarism in the high-sounding moralistic language of Confucianism. The ironic effects achieved by Lu Xun in this work made it not only the first short story of modern Chinese literature, but also one of the best.

With the exception of "Remembrances of the Past" (written in I9II), Lu Xun wrote all his short stories between I9I8 and 1926. The first fourteen of them, collected under the title Cheering from the Sidelines, were completed over a five-year period between I9r8 and 1922, while the eleven published in Wondering Where to Turn 
were all written within two years, during 1924 and 1925 . Lu Xun was probably enabled to create these stories at this particular time because China was at last undergoing exactly that kind of revolution in culture that he and his brother had sought to encourage ten years before from Japan. Although various names have been used to refer to this Chinese cultural transformation, they are all misleading terms in one way or another. But since "May Fourth Movement" is the most commonly known of the historical epithets emerging from the period, we will adopt the term hereafter in reference to the events of this time.

Essentially, the developments leading up to the May Fourth Movement may be summarized as follows: after the abolition of the examination system, increasing numbers of Chinese youths received modern educations, both at home and abroad. As a result, the scope and audience of the mass print media widened, and these young people gradually became a force for change in China. The impetus to change was twofold. Imperialism from abroad threatened to end China's existence as a sovereign state, and feudalism at home in the form of traditional social patterns stifled innovation and freedom of choice among the young. After the establishment of the republic, the two evils were often perceived as symbiotically related-foreign imperial powers supported their favorite reactionaries in exchange for continued enjoyment of special privileges in China.

During the Versailles Peace Conference at the conclusion of World War I, news leaked out in China that Duan Qirui's warlord government in Beijing had agreed to let Japan take over Germany's "rights" in Shandong Province in exchange for Japanese military support that would enable Duan to put down his own competition at home. On May 4, 1919, students in Beijing staged a mass demonstration protesting the government's "sell-out" of the Chinese nation. Further demonstrations, student strikes, and boycotts of Japanese goods soon swept the major cities of China, until on June 28 Duan's government finally gave in to public pressure. Whatever Duan's original intentions may have been, the Chinese delegation in Versailles refused to sign the treaty. The students and their supporters had mounted a nationwide public opinion campaign against the government, and they had won.

This mass movement identified itself with, and gave fresh impetus to, the revolution in culture that had already begun in 1915 
when a small group of capable young men began to publish a journal in Shanghai known as New Youth. Devoted to cultural, literary, and political themes, its material was written in literary Chinese in the same style as all serious journals of the time. Throughout Chinese history, the scholar-officials who governed the land and set the standards in matters of literary taste had considered colloquial Chinese, the language of everyday speech, appropriate only for popular novels. For any serious purposewriting essays, history, letters, government documents-one had to write in the classical literary language, the language of the Confucian Analects and the Mencius, both written over two thousand years before. This was the language of serious books, a language one had to see written out in characters. Read aloud, it was not altogether intelligible-unless of course one quoted from one of the classics he had memorized as a youth preparing for examinations and a career in the civil service. Thus, it was nothing less than a bold and revolutionary step when, in 1918, these avantgarde young men began publishing New Youth in the colloquial language. Dismissing the form in which Chinese culture traditionally expressed itself, their attack on its substance was doubly effective.

Many of these young men were invited at about this time to join the faculty of Beijing University by Cai Yuanpei, the new and vigorous chancellor who had come to office in 1916 and had single-handedly transformed the university, changing it from an upper-crust school whose frivolous and wealthy students had once earned themselves the nickname "Brothel Brigade" into modern China's most prestigious institution of higher learning.

Lu Xun wished the New Youth group well. He had, however, become so disillusioned by the successive spectacles of a stillborn republic, two attempts at imperial restoration, and rampant warlordism that he could no longer approach the work of cultural transformation with the same high hopes he had held as a student in Japan ten years before. Within a few years, in his preface to Cheering from the Sidelines, ${ }^{17}$ he would recall:

17. Published in 1923. As Wang Chi-chen first pointed out, the Chinese title Nahan suggests "cheering from the sidelines" in contrast to active participation. See Wang's "Lusin: A Chronological Record," China Institute Bulletin, vol. 3, no. 4 (January 1939). 
They were in the midst of publishing New Youth at the time. However, not only had no one come forward to approve of what they were doing, but no one had yet bothered to mount an opposition to it either. I knew that he [Qian Xuantong] must be feeling very lonely. Nonetheless, I gave this reply: "Suppose there were an iron room with no windows or doors, a room it would be virtually impossible to break out of. And suppose you had some people inside that room who were sound asleep. Before long they would all suffocate. In other words, they would slip peacefully from a deep slumber into oblivion, spared the anguish of being conscious of their impending doom. Now let's say that you came along and stirred up a big racket that awakened some of the lighter sleepers. In that case, they would go to a certain death fully conscious of what was going to happen to them. Would you say that you had done those people a favor?"

"But since I'd awakened some of them, you can't say that they would have absolutely no hope of finding some way to break out."

Yes, he had his point. Though I was convinced to my own satisfaction that it wouldn't be possible to break out, I still couldn't dismiss bope entirely, for hope belongs to the future. My conviction that such a thing would never happen wasn't sufficient grounds for entirely dismissing his hope that it might.

How seriously we are to take the studied negativity of Lu Xun's writing is a matter open to question. Ever concerned lest easy optimism soothe his readers into the same lethargy from which he sought to rouse them, Lu Xun remained rigorously pessimistic in his writing.

The period during which Lu Xun wrote his stories saw many changes in his private life. Ever since 19I2, he had lived in the Shaoxing Club, a hostel that had been established by native Shaoxing men living in the capital. ${ }^{18}$ In 1919, however, Lu Xun bought a house, traveled back to Shaoxing, sold the ancestral property there, and moved his family north to Beijing. The experiences of that trip provided material for one of Lu Xun's most beautiful and moving stories, "Hometown." The property he

I8. There were many such hostels (huiguan) in Beijing, each established by men sharing common geographic origins, or sometimes a common occupation. 
bought in the capital must have been fairly large, for in addition to Lu Xun himself, his wife, and mother, it also had to accommodate his two younger brothers, Zuoren and Jianren, as well as their wives and children.

In 1920-the year when the Ministry of Education declared the colloquial language to be the official medium of instruction throughout all of China-Lu Xun began to lecture on the history of Chinese fiction at Beijing University, in a course that eventually resulted in the first book-length study ever devoted to this subject. ${ }^{19}$ Because women's emancipation contributed so much to the spirit of the May Fourth Movement, and was also so central a theme in Lu Xun's stories, we may also mention here that it was in the year 1920, too, that Beijing University first began to admit female students.

Two years later an intriguing foreigner, Vasily Eroshenko (I889-I952) arrived in Beijing. Born in the Ukraine, this blind Russian poet had lived in India, Burma, and Japan before coming to China. ${ }^{20}$ In 1922 Cai Yuanpei invited him to Beijing University to lecture on Esperanto, a language in which he was something of an expert. But where would the university put him up? The solution, of course, was to put him at the Zhou family's house. Eroshenko knew no Chinese whatsoever but he spoke Japanese fairly well. What better place than the Zhou establishment, where Japanese was practically a second language. In fact, the pleasant stay with $\mathrm{Lu}$ Xun's family that was enjoyed by this Russian visitor is reflected in the stories "Some Rabbits and a Cat" and "A Comedy of Ducks."

But the family harmony that Lu Xun had hoped to enjoy did not last long, for he and Zuoren had a serious falling out-apparently because Lu Xun and Zuoren's wife could not get along togetherbringing the situation to such a state that in 1923, accompanied by his wife and mother, Lu Xun finally moved out of the house. ${ }^{21}$ It is difficult to establish in retrospect what was the exact nature of the quarrel, for neither brother ever discussed it in print. However,

19. A Brief History of Chinese Fiction, translated by Yang Hsien-yi and Gladys Yang (Peking: Foreign Languages Press, 1959).

20. Eroshenko had been deported from Japan in I92I on suspicion of being an anarchist.

2r. The new home that Lu Xun bought after moving out of the family quarters is now the site of the Lu Xun museum in Beijing. 
the strain on their relationship did find its way into "Brothers," the only story where Lu Xun treats dreams as windows to the subconscious.

In his new and somewhat smaller quarters, the tempo of $\mathrm{Lu}$ Xun's writing increased, so that within two years he had completed the eleven stories collected in Wondering Where to Turn: he wrote four in 1924 and seven in 1925 .

Beginning in 1925, personal and political events conspired to radicalize Lu Xun, to move him increasingly away from the indirect critique he could make through fiction writing to the open criticism of the political essay. A sinecure at the Ministry of Education, his literary research, creative writing, and part-time teaching posts-these had largely filled his life up to now. But from this point until his death in 1936 it would be student demonstrations, leftist organizations, occasional periods in hiding to avoid arrest, satirical essays written by the score, the support and encouragement of the leftist woodcut movement, and-yes-even love.

In 1906, as we have seen, Lu Xun had entered into an arranged marriage according to his mother's wishes. But while he had assumed financial responsibility for his first wife, he never loved her. And so far as we know there was no romance in his life whatsoever until 1925, when Xu Guangping, pretty, bright, and more than twenty years his junior, began to write to Lu Xun. ${ }^{22}$ A Cantonese who had fled her home rather than submit to an arranged marriage, Xu Guangping was at this time a student at the Women's Normal College in the capital and had attended Lu Xun's classes there. Soon after initiating correspondence with her esteemed teacher, she became leader of a student movement organized to protest the Minister of Education's appointment of a conservative woman to the top position at her college. Lu Xun sided with the students and was temporarily dismissed from his post at the ministry. But this was a time of discontent outside the campus too: the people of Beijing were disappointed and disgruntled with the posture of the warlord government vis-à-vis the unreasonable demands of imperialistic foreign powers. In March of 1926, when a large group gathered before the Government House to protest

22. A record of their correspondence is preserved in Letters From Two Places (Liang di shu), published in 1933. An English translation is presently in preparation at Foreign Languages Press in Beijing. 
the weak-kneed official attitude, police fired into the crowd, killing forty-seven and wounding one hundred and fifty people. One of Lu Xun's own students from the Normal College was among the dead. The vitriolic essays he wrote condemning the government for the atrocities committed on "this darkest day since the founding of the republic" caused Lu Xun's name to be placed on a list of fifty radicals who were marked for arrest. At first he went into hiding but then, toward the end of summer and accompanied by Xu Guangping, he fled Beijing.

She proceeded straight to a teaching post at the Women's Normal School in Canton while Lu Xun went on to assume a position at Amoy University that had been offered him by Lin Yutang, then dean of the College of Literature, who later would become internationally famous for his writings about China in English. Lu Xun was not happy at Amoy, in part because he shared little in common with the faculty there, a group of professors mostly AngloAmerican in orientation. In part, however, we may assume that Lu Xun simply wanted to be reunited with Guangping. At any rate, he soon left Amoy to accept a position at Sun Yat-sen University in Canton.

While Lu Xun was teaching in Canton, Chiang Kai-shek's Nationalist Party adopted its policy of purging communists from its ranks, although they had been welcome as members since 1924 . The subsequent bloodbath drove the vast majority of independent Chinese writers to the left, politicizing many who had previously taken only marginal interest in the state of society at large. ${ }^{23}$ During the violence created by the purge, some of Lu Xun's own students were arrested and he was now powerless to help them.

In the fall of 1927, Lu Xun and Xu Guangping moved to Shanghai, where they lived as man and wife. Two years later they had a son, Haiying, Lu Xun's only child. Lu Xun would spend the last nine years of his life in modern China's most cosmopolitan, and most revolutionary, city. During these years he would devote his prodigious energies to cultivating younger writers, fostering the woodcut movement, translating, founding short-lived publishing ventures, lecturing, campaigning for the simplification of Chinese

23. The Nationalist Party had cooperated with the Communist Party since 1923 in forming a United Front against warlordism, but in 1927 it launched this brutal and bloody series of purges in a move to rid itself of all leftist influence. The purges were collectively known as the White Terror (baise kongbu). 
characters and their eventual replacement by an alphabetic writing system, and composing scores of the short, biting essays known as "miscellaneous writings" (zawen). Here in Shanghai Lu Xun would come to know communist activists and writers, would go underground himself to avoid possible arrest and execution, and would grow into the grand old man of China's leftist culture.

One after another, pulling them up from a seemingly inexhaustible source, Lu Xun hurled his daggerlike zawen at the Nationalist Party and all its rightist sympathizers. Terse, incisive, satirical in tone, and inimitably idiosyncratic, zawen flowed from his pen so rapidly and in such volume that they soon constituted the bulk of his creative work. Indeed, critics in the People's Republic of China have often valued Lu Xun's zawen over all his other writings, claiming they contributed more not only to literature but also to the Revolution. No contemporary of Lu Xun was able to match his achievement in this essay form, either in clarity of thought or brilliance of style. His zawen inspired a host of imitators, but none of them came even close to approximating the master's graceful yet deadly style. So popular were these politically charged pieces that writers in the communist base camps during the Anti-Japanese War (1937-45) attempted to use zawen "scalpels" to remove what they diagnosed as "malignant excrescences" within their own ranks. Finally Mao Zedong himself put an end to the practice, commenting that $\mathrm{Lu}$ Xun had employed the lethal zawen style only against his enemies.

The burgeoning of left-wing literature that followed in the wake of the terrifying purges of 1927 occasioned intense debate in China as to what leftist literature really should be. Lu Xun took part in these polemics and translated works of Soviet criticism, hoping to elevate the level of debate. The extent of his own leftward shift may be seen from the fact that in his inaugural address to the League of Left Wing Writers, an organization he helped found in I930, Lu Xun suggested that the primary task of writers should be to serve the workers and the peasants. Given Lu Xun's view of Chinese society, this was a natural development in his thinking. But while he favored literature written in the interests of the workers and peasants, he scorned writers who pretended to know what workers or peasants actually thought and felt. Finally in I93I, observing that no contemporary left-wing writer actually came from peasant or worker stock, he said that the best works left- 
wing writers could reasonably hope to produce would be novels of "exposure," works depicting the revolt of petit bourgeois writers against their own class.

Throughout this period Lu Xun continued to argue against whatever he saw as illogical literary dogma, whether on the right or on the left. Against the rightists, he maintained that "human nature" in the abstract simply does not exist: in actual society one finds only class nature. Against the leftists, he pointed out that while it is true that all literature is propaganda, the reverse proposition does not hold-only edifying propaganda can be counted as literature. Understandably, Lu Xun was in his turn attacked from both the right and the left, but his own sympathies never wavered: he stood clearly on the left and maintained that anyone claiming to stand "in the middle" was a simply a rightist in disguise.

Since his earliest childhood Lu Xun had enjoyed reading illustrated books, and as he grew to adulthood he became exceptionally well informed about the history of woodcut printing in China. Little wonder, then, that he became an enthusiastic supporter of the Eighteen Society, formed in 1929, the eighteenth year of the republic. This was a group of revolutionary artists whose slogan was "out of the salon and into the streets." Lu Xun was drawn to their movement because woodcuts could readily be bent to political commentary, as Soviet and German artists had already demonstrated. In January of $\mathbf{1 9 3 6}$, the last year of his life, Lu Xun wrote a preface to his own selection from the graphic art of Käthe Kollwitz, a German artist whose socialist and pacifist ideas he much admired. He commented that she had paid more attention to China than China had paid to her, for in I93I she had been one of the signers to a letter of protest sent by the Progressive Writers and Artists of the World when the Nationalist Party secretly executed five young left-wing writers in Shanghai.

In literature and in art, then, Lu Xun consistently favored breaking down China's cultural walls so that she might look outward to the world-not to imitate, but to learn, and to share as well. As we have seen, he believed that China's cultural strengths shared the same cause as her weaknesses: her isolation from other major centers of world civilization, an isolation that had allowed China to develop independently, free from outside influence, but that also had deprived her of outside stimulation. Because of this belief, Lu Xun had been since early youth an ardent champion of 
translation and had himself become a prolific translator. In these final Shanghai years, too, he continually urged his fellow writers to bring more works of foreign literature over into Chinese, for translations, he argued, would make a greater contribution to the people than volumes of shoddy original work.

Four years after Lu Xun's death, Mao Zedong wrote of him:

Lu Xun was a man of unyielding integrity free from all sycophancy or obsequiousness; this quality is invaluable among colonial and semicolonial peoples. Representing the great majority of the nation, Lu Xun breached and stormed the enemy citadel; on the cultural front he was the bravest and most correct, the finest, the most loyal and the most ardent national hero, a hero without parallel in our history.

Coming from Mao Zedong, such praise had the effect of virtual deification. Yet there is a certain irony in the fact that Lu Xun, a man who made a lifetime career of idol smashing, has himself become an idol over the years. In addition to the museums now devoted to him in China, there are photographs, posters, scrolls, and even hand-painted statues sold by the thousands.

Lu Xun responded to the dilemma posed by the massive onslaught of Western culture not by praising the glories of Chinese antiquity, nor by recommending wholesale westernization, but rather by helping China to look outward (through his translations) so that she might take her place in the modern world representing one civilization among many. He responded by attacking the old Confucian "man-eating" society at home (through his stories and zawen), a society so riven by inner conflicts that it could neither learn from the Western powers nor defend itself against their greed. During his earlier career he had already diagnosed China's illness, but he had no cure to offer. Later during the Shanghai years he took heart from the example of the Soviet Union and came to believe that communism would eventually bring about the cure: a classless society, one that would nurture the good in people rather than turning them into copies of $A h Q$, the victimized and pathetic antihero of his longest and best-known work of fiction. At a time when his people were divided at home and despised abroad, it was the genius of Lu Xun that he could see himself as part of a world community of right-hearted people working for a better future. More than just a great writer, and without a trace of 
the sentimentality that often clings to those who preach the brotherhood of man, Lu Xun was one of our century's great internationalists.

\section{The Stories}

To characterize the twenty-five stories in Cheering from the Sidelines and Wondering Where to Turn, the term "classic" comes readily to mind. In the People's Republic of China, they have been read and reread; they are the subjects of seemingly endless commentary; and they have become the standard against which later works are measured. Varied in form, the stories draw on a mixture of influences, both Chinese and foreign, even while such influences do not provide, either singly or in combination, a simple explanation for these distinctive works. They are their own stories just as Lu Xun was his own man. Apart from their literary value, however, Lu Xun's purpose in writing each one of them was essentially the same as his larger purpose in turning from medicine to literature in the first place-he wanted to transform the Chinese psyche.

During his student days in Japan, Lu Xun and his lifelong friend Xu Shoushang often discussed three interrelated questions:

I. What is the nature of the ideal human being?

2. With respect to this ideal, what are the greatest deficiencies in the Chinese character?

3. What is the reason for these deficiencies?

With regard to the stories, their answer to the second question is most significant. They decided the most glaring deficiencies in the character of the Chinese people were (I) lack of love and compassion (ai), and (2) lack of honesty and integrity (cheng). This had come about, they concluded, because China had been twice occupied by foreigners: the Mongols who had established the Yuan dynasty (1279-1368) and the Manchus who established the Qing (I644-I9II).

Close reading of the stories will show that by lack of honesty $\mathrm{Lu}$ Xun meant primarily the hypocrisy that arises when one either turns away from a painful reality or glosses over it with dishonest thinking until it is no longer recognizable for what it actually is. 
Thus in "Soap" the middle-aged protagonist, whose Confucian upbringing has trained him to avert his eyes from all that is unseemly, cannot admit that the enthusiasm of his praise for the exemplary filial piety of an eighteen-year-old girl he encounters on the street stems more from his own repressed sexual desire than from admiration for her morality.

Lack of love and compassion is perhaps most poignantly documented in "Kong Yiji," where patrons at the Prosperity for All wineshop continue to taunt the failed old scholar even after both his legs have been crippled as punishment for stealing books and he is reduced to dragging himself about on his hands.

But if the Chinese people as a whole were deficient in love and in honesty, was Lu Xun exempt from the same charge? He himself provides an answer in an essay written in 1926: "It is quite true that I often dissect other people, but even more often-and more ruthlessly-l dissect myself." 24 The story "Brothers" is a case in point. Written two years after Lu Xun's split with Zhou Zuoren in 1923, it portrays the ostensibly selfless love of an elder brother for his younger brother in contrast to the specters of hostility that emerge at night in the elder brother's semiconscious dream awareness. Though we cannot be certain of the relationship between this story and Lu Xun's own personal life, it seems likely that in writing it he was indeed dissecting his own psyche, for from all testimony he had played just such a self-sacrificing role vis-à-vis Zhou Zuoren.

It is significant that almost half the stories are presented through a first-person narrator who usually, though not always, bears some resemblance to what we know of Lu Xun's personality. Indeed, Lu Xun was himself very much a part of the world he wrote about. He seldom analyzed it without also analyzing himself.

Still more complex are the "self-dissections" that take place in "Upstairs in a Wineshop" and "The Loner." In each of these stories, mirroring Lu Xun's own experiences, a young intellectual leaves a backwater childhood behind and receives a modern education that renders him politically and culturally sophisticated, so that he is no longer content with the status quo and longs for

\footnotetext{
24. "Postscript to Tomb" (Xie zai Fen houmian), in vol. I of $L u$ Xun quanji (Beijing: Renmin wenxue chubanshe, $198 \mathrm{I}$ ), p. 284.
} 
change. In the end, each of them fails, victimized by society and by the weaknesses in his own personality. Both stories are told by first-person narrators who, in the end, walk away from the failed protagonists with a sense of relief. Lu Xun shared many of the problems that weigh upon the protagonists of these two stories, but unlike them he chose hope instead of despair; like his first-person narrator, he walked away from the negativity represented by these two men. They stand for one side of the first-person narrator and one side of Lu Xun; they are what Lu Xun and his first-person narrators might have become. In real life, Lu Xun had a friend very much like the protagonists of these two stories in the person of Fan Ainong (1883-1912).

Since both these protagonists are partly based on Fan, let us pause for a closer look at this singular man. A native of Shaoxing, Fan was one of the student group that $\mathrm{Xu}$ Xilin had taken with him to Japan in 1905 , to study and to make revolution. Though Lu $\mathrm{Xun}$ had accompanied the delegation that went to welcome $\mathrm{Xu}$ Xilin and his students on their arrival in Japan, he had not taken any special notice of Fan Ainong. It was not until two years later that Lu Xun really noticed him-and then it was with contempt. A student meeting had been called to discuss the execution of Qiu Jin in Shaoxing as well as the barbaric circumstances surrounding $\mathrm{Xu}$ Xilin's death. ${ }^{25}$ Most of the students, Lu Xun included, favored sending a telegram of protest to the imperial government in Beijing. Fan Ainong, seeing no point in what he referred to as their "stinking telegram," opposed them. Since Fan had been a student of Xu Xilin's, Lu Xun was outraged at such apparent detachment. In the end the telegram was sent, and Lu Xun was not to see Fan Ainong again for four years.

Having lost both his parents as a boy, Fan had been brought up by his grandmother. Upon her death, the uncle who was left in charge of the family finances refused to continue supporting his studies in Japan. Fan was forced to return to China where, since he was known as a student of Xu Xilin's, the government watched him closely. After a stint teaching at the Shaoxing High School, he went off into the countryside and, like the protagonist of "Upstairs

25. Lu Xun describes this meeting in "Fan Ainong," the last of ten reminiscences written in 1926 and published as Zhaohua xishi (Dawn Blossoms Plucked at Dusk). The English translation is by Yang Hsien-yi and Gladys Yang (Beijing: Foreign Languages Press, 1976). 
in a Wine Shop," eked out a living there as a private tutor. Whenever he felt demoralized, he would boat into Shaoxing ${ }^{26}$ to visit the wineshops for some serious drinking. On one of these excursions in I9II he ran into Lu Xun, who later remembered having been somewhat surprised by Fan's changed appearance-his hair had turned grey and his seedy clothing suggested poverty. But this time, at any rate, he and Fan hit it off well. Thereafter, whenever Fan came to town he would bypass the wineshop and make for Lu Xun's place, where the two would chat and drink late into the night, often saying such extravagant things while well into their cups that Lu Xun's mother would laugh to overhear them. Lu Xun and a friend across the table from him over wine-it was a scene that would be reflected in both "Upstairs in a Wine Shop" and "The Loner." This was, moreover, no ordinary friend but one who, like the protagonists of those two stories, reflected the negative side of Lu Xun's own personality, one who fleshed out the possibility of failure.

When revolutionary troops liberated Shaoxing in the wake of the Republican Revolution later that year, the new military governor, Wang Jinfa (1882-1915), made Lu Xun director of the ShanKuai Primary Level Normal School and Fan Ainong dean of studies. For a brief period Fan was a changed man; he cut down on his drinking and wholeheartedly devoted himself to his new job. Soon afterwards, however, Lu Xun left Shaoxing to join the new Ministry of Education in Nanjing, and the director who succeeded him, a stodgy Confucian moralist, made things so unpleasant for Fan Ainong that he was eventually forced out of his job.

An abrasive fellow who found it difficult to get along with anyone, Fan found it impossible to secure another post and was soon reduced to real poverty. He pinned his remaining hopes on $\mathrm{Lu}$ Xun's finding him some sort of position at the ministry and wrote several times begging him to do so. In his depression he drank more and more heavily, and finally either fell or leapt-since he was intoxicated at the time, it is not clear which-to his death from a boat while returning one evening from an opera.

While Fan may have been the victim of an unfortunate environ-

26. The countryside surrounding Shaoxing is crisscrossed by canals. In this area boating was and still is a common form of travel. A boating expedition to and from a local opera is described in loving detail in "Village Opera." 
ment, he was no doubt also the victim of his own idiosyncracies. He seems to have been a man who could never quite fit in, no matter where he was. One likely reason is that although he lived in a society built around carefully and minutely prescribed social distinctions based on position in the family, class, education, bureaucratic status, age, wealth, and so on, Fan behaved as though the social hierarchy did not exist. He simply ignored it, as does the protagonist of "The Loner" early in that story. Moreover, even after the military governor made Fan dean of studies at the normal school, he continued to wear the same shabby costume he always had worn-in fact, Fan dressed like a peasant, right down to the conical felt hat so typical of Shaoxing farmers and boatmen. ${ }^{27}$ It is likely that Lu Xun admired this quirk in Fan Ainong, though he himself was largely a conformist in the matter of clothing.

Fan and the military governor Wang Jinfa had both been among the students taken by Xu Xilin to Japan, but Fan can hardly have known Wang well enough to justify the familiarity of his behavior in Wang's office on one particular day when he addressed the governor as "old chum," rubbed his palm back and forth across the military man's shaved head, and bemusedly congratulated him for having risen to so high a position. Fan's utter unawareness of-or perhaps it was contempt for-the social pecking order must have fascinated Lu Xun, who had come to see hierarchy as one fundamental problem of Chinese society.

Lu Xun received news of Fan Ainong's death on July 19, I9I2. Three days later, after attending a farewell banquet for Cai Yuanpei, who had now been forced out of office by the conservative faction at the Ministry of Education, Lu Xun wrote three poems lamenting his old friend Fan. The last one of them said:

While storms rage across the land,
memory's eye turns to Fan Ainong:
the grey of hair, so sparse and thin,
the whites of eyes turned in scorn
from bootlickers scrambling for place. ${ }^{28}$

27. Such hats are still worn today, and they are also sold to tourists at the souvenir stand in the Shaoxing Hotel.

28. In the original text, this line contains a pun on the name of a man well known to Fan and Lu Xun for sycophantic flattery toward his superiors. 
And yet the world has never liked a food

that leaves a bitter taste;

nor will it long abide a man

whose words and ways are straight.

Still, who would have thought that

just three months after our parting,

you'd leave forever this world

in which you never fit?

It seems very likely that for Lu Xun, Fan represented negativity and despair. The protagonists of "Upstairs in a Wineshop" and "The Loner" both serve a similar function in relation to the firstperson narrators who, at the end of each story, finally turn away from the hopelessness represented by these characters to get on with the business of life. And what was Lu Xun's own attitude toward the to-be or not-to-be of existence? At the end of "Hometown"-a story that reflects Lu Xun's I9I9 trip down to Shaoxing to sell the family property and move his wife and mother north to Beijing - the narrator, having experienced profound despair at the changes in people he had fondly pictured through the distorting lens of childhood memory, offers this definition of hope: "Hope isn't the kind of thing that you can say either exists or doesn't exist. It's like a path across the land-it's not there to begin with, but when lots of people go the same way, it comes into being." Love and honesty, too, are not waiting out there somewhere to be found, but rather come into existence when people practice them. Here and there in the stories, we occasionally find characters who bring them into being. In "An Unimportant Affair," for instance, a simple rickshaw man shows through his actions that integrity and compassion do exist, by simply creating them before the astonished eyes of the narrator.

The best known and best loved of all his works of fiction, "Ah Q-The Real Story," is perhaps also the most eloquent of all the stories in documenting what Lu Xun saw as a lack of love and honesty in Chinese society. The only one of his works to employ the diction and structure of traditional Chinese popular fiction, "Ah Q-The Real Story" is a long and rambling tale that first appeared in serial installments in a newspaper. By his own testimony, in the character of his vagabond, ne'er-do-well protagonist 
Lu Xun attempted to sum up all the psychological weaknesses of the Chinese people, the most debilitating of which was the inability to face up to the here and now of reality.

Unable to cope with the present, Ah Q flees into fantasies of a past in which his ancestors were rich and powerful (conservative Chinese scholars of the period were boasting of the glories of ancient China while disdaining the Johnny-come-lately accomplishments of the West) or escapes into a future in which his unborn children will be. When temporal escape is not feasible, Ah $Q$ rationalizes failure into success; the reader sees him suffer defeat after defeat, each of which is immediately transformed into an inner, psychological victory. Such was the impact of the story that "Ah Q-ism" and "psychological victory" became staple terms of everyday conversation in China, and these terms are still occasionally used even today.

Apart from this psychological emphasis, "Ah Q-The Real Story" has historical implications as well. Set against the background of the Republican Revolution of I9II, the story lays bare with a few deft strokes the fatal weakness of that revolution: it had been a movement of the privileged, by the privileged, and for the privileged. The common people had not been involved. Here, as in much of his literary corpus-especially the satirical political essays to which he devoted most of his creative energies during the last decade of his life-Lu Xun showed an unusual gift in his singular ability to see clearly and to articulate succinctly what others had only suspected or dimly perceived.

In the world through which Ah Q moves, we see a lack of honesty and integrity at every turn, but still more disturbing is the utter lack of love and compassion that the story reveals as it unveils the society of Wei Village. This is a world where the strong bully the weak and the weak fawn over the strong. Power, money, prestige, and position in the hierarchy-these are all-important; love and compassion count for nothing.

The sixth entry of Lu Xun's first colloquial story, "Diary of a Madman," reads:

Pitch black out. Can't tell if it's day or night. The Zhao family's dog has started barking again.

Savage as a lion, timid as a rabbit, crafty as a fox . . .

This passage provides a good example of Ju Xun's style. He demanded that his readers approach his work with an active atti- 
tude of participation, and this is especially true of the stories. He disdained the traditional Chinese concept of fiction, which allowed the work only a limited role as a form of entertainment, a diversion the passive reader might use to while away the time. Within the context of "Diary of a Madman," Lu Xun expects the reader to perceive that entry six ("Pitch black out . . .") has articulated a basic truth about the world the madman inhabits. That world is a hierarchical nightmare where strong individuals bully the weak with the fierceness of a lion, while the weak victims fawn over the strong with the timidity of a rabbit. And when two people are unsure-on first meeting perhaps-of their relative positions in the lion-rabbit order of things, they behave with the craftiness of foxes until they are.

In his emphasis on the hierarchical nature of Chinese society, it is likely that Lu Xun was strongly influenced by Zhang Taiyan. ${ }^{29}$ Zhang started from the assumption that the Chinese people needed a religion to promote their morality and to inspire their own faith in themselves. Whatever its other excellences, Confucianism could not serve this function because it was inextricably linked with status and privilege. Buddhism, on the other hand, was more egalitarian and had potential to unite people of high and low station in Chinese society. Unlike Confucianism, Buddhism was in its very spirit incompatible with class distinctions and should therefore prove attractive not only to the masses but also to intellectuals.

Lu Xun never accepted the proposition that Buddhism could save China. Nonetheless, Zhang Taiyan, through his criticism of the hierarchical nature of Confucianism, and because of the importance he attached to including the common people in any solution to China's many woes, exerted an influence on Lu Xun. During his period of relative hibernation in Beijing, between 1912 and I918, Lu Xun made his own study of Buddhism and there is little doubt that his understanding of Chinese society was influenced by it. If we can speak at all of heroes and heroines in his stories, they are invariably individuals who represent the groups in Chinese society for whom Buddhism had the greatest appeal: women of all classes and the common people.

29. The summary of Zhang's thought that follows is based on Michael Gasster's Chinese Intellectuals and the Revolution of 1911 (Seattle \& London: University of Washington Press, 1969), pp. 198-200. 


\section{The Translations}

Translating Lu Xun is difficult, for like Gogol-whom he so much admired-Lu Xun was a stylist. That is, we remember not only what he said, but also how he said it. His narrative voice is as distinctive as his thought. The Russian critic Kornei Chukovsky has described Gogol's style in words that apply equally to that of Lu Xun:

Gogol's style is characterized first and foremost by startling verbal colors brought to such a dazzling shine that one delights in every line as a gift. And though you may know the entire text by heart, it is impossible to get used to its sustained revolt against the dull banality of predictably stereotyped speech and fixed, moribund forms. ${ }^{30}$

Is it possible, then, to translate a style as idiosyncratic as either Gogol's or Lu Xun's? This question is not easily answered. Chukovsky, playing the role of prosecuting attorney, criticizes a translation of The Inspector General that was published in the United States by Bernard Guilbert Guerney:

Mr. Guerney was honor bound to reflect all this revolt against dead blandscript in the language of his translation, because this is precisely where the essence of wonder-working Gogolian stylistics lies. Not to reproduce this essence means not to give foreign readers the slightest notion of what Gogol is about. What Russian when he speaks of The Inspector General does not delightedly recall his favorite Gogolisms, without which The Inspector General is not The Inspector General to him? There is good reason why immediately after the appearance of The Inspector General all his quotable expressions and words were immediately taken into the everyday language by progressive young people of the time. ${ }^{31}$

Having leveled these charges, Chukovsky, who presents this discussion of the translator's art in the style of a courtroom trial, then turns about to play the role of defense attorney, pointing out the near-impossibility of bringing a style across from one language into another:

30. Kornei Chukovsky, A High Art, trans. Lauren G. Leighton (Knoxville: University of Tennessee Press, 1984), p. I22.

3I. Chukovsky, pp. 122-23. 
So it is pointless for the prosecutor to attack Bernard Guilbert Guerney ... with such unseemly fervor and to see in ... blandscript something so serious as sabotage. It is impossible to bring people to trial because they are not magicians and cannot perform miracles! ${ }^{32}$

Blandscript or an attempt at style? It is a difficult choice. I have opted for the attempt to suggest something of Lu Xun's style in English, for more than any other modern Chinese author, Lu Xun is inseparable from his style. I have tried to recreate the experience of reading $\mathrm{Lu}$ Xun in Chinese, often asking myself the question, "How would he have said this if his native language had been American English?"

One of the hallmarks of Lu Xun's style involves the contrast between the classical or literary language (wenyan) and the colloquial (baibua). To be sure, his stories are written in the colloquial language, but it is a highly stylized colloquial, studded with words, phrases, and whole quotations from the classics. ${ }^{33}$ This makes for a style that is particularly suited to the intention of the stories in that Lu Xun almost invariably quotes the classical language in a satirical vein, so as to disparage the tradition that language represents. Since in English we do not have ready access to a classical register, such contrasts are difficult to reflect in translation. ${ }^{34}$ Throughout my translations I attempt to suggest these contrasts in a variety of ways: by using an inflated style; by italicizing certain words and phrases; by rhyming certain lines that were not rhymed in the original text; or by using some combination of these devices. ${ }^{35}$

By risking looseness in translation, I hope I have remained faithful to Lu Xun's texts. I have translated as I think Lu Xun might have written had his language been American English rather than Chinese. Chinese and English are very different languages and

32. Chukovsky, p. זзо.

33. When I first looked through Lu Xun's letters, I was surprised to find that he could on occasion -in responding to the letter of a high school student, for example-write in a flat, purely colloquial and undistinguished style.

34. At an international conference on Lu Xun and his legacy held at Asilomar, California, in the summer of $198 \mathrm{I}, \mathrm{I}$ touched on this problem in a question posed to Irene Eber of the Hebrew University of Jerusalem. Since Hebrew does encompass both a classical and a colloquial register, she happily reported that the same problem does not complicate the task of translating Lu Xun's stories into that language.

35. For example, the entire opening paragraph of "Diary of a Madman" is italicized and phrased in a stilted idiom. 
being too true to one (except in the bloodless prose that one sometimes encounters in social science writing) can mean being false to the other.

In translating the stories, too, I constantly ran into the problem of selecting a tense, a problem that points up one characteristic of Lu Xun's style as well as a certain peculiarity of the Chinese language. As a language, Chinese concerns itself much more with the sequence and logic of events than it does with the exact time when those events occurred. In Chinese it is of course entirely possible to be precise in the matter of tense, but the point is-and this makes for numerous possible literary renderings-that one does not have to be so. This is one of the reasons it is virtually impossible to translate a Chinese poem into English: so many of them are cut free from time. They come to life and happen while you read them. Translate such a poem into English, add whatever inflections you deem appropriate, and though the translated poem may still reflect something of its original beauty, it will invariably lose the timelessness it had in Chinese. Similarly, many of Lu Xun's stories are written in a prose so sparsely supplied with the usual tense markers that their style approaches poetry.

I was particularly struck by the problem of establishing a tense in the course of editing my own translations. It baffled me to find that some seemed so different from the originals. I compared my own work with other translations and found that they also failed to reflect the kind of experience I enjoyed when reading the stories in Chinese. Finally it dawned on me that when I was reading the original text, I did not feel that what I was reading was happening in the past. This seemed to be especially true of the story "Medicine." So I then tried recasting the entire translation in the present tense and, though the result seemed forced in one or two places, on the whole it conveyed a more accurate reflection of the original Chinese than my initial translation had done. Aside from "Medicine," I have also recast "The Eternal Lamp" and "A Warning to the People" in the present tense. But the fact remains that in Chinese an artist like Lu Xun can fine-tune his tenses by suggestive degrees. Since in English we have only an off-on switch, there is no ideal solution to the problem.

All the stories in this book have been ably translated before. ${ }^{36}$

36. So far as I know, the only one for which I can claim a "first" is my translation of "Brothers," which first appeared in the inaugural issue of Renditions in 1973. 
The first translation to be widely known in the United States was Wang Chi-chen's $A b Q$ And Others (I94I), which included a critical introduction and eleven stories. Wang rendered the stories into a smooth and fluent American English. Next came the magnificent four-volume Selected Works of Lu Hsun by Yang Hsien-yi and Gladys Yang of the Beijing Foreign Languages Press (1956-1960), the first attempt at a systematic introduction to Lu Xun in English. The first volume contains eighteen stories along with a generous sampling of Lu Xun's prose poems and reminiscences, while the final three volumes consist entirely of the daggerlike zawen, essays on political and cultural themes for which he was justly famous. More recently the Yangs have also published a complete translation of the stories in two volumes, entitled Call to Arms and Wondering (both 1981). ${ }^{37}$ Since the Yangs translate into a British English, however, I am entitled to the modest claim of being the first to translate all of Lu Xun's stories into the American branch of the language.

In supplying notes to the stories I have, if anything, erred on the side of abundance: a translator should provide enough documentation to ensure that the reader can achieve roughly the same understanding - or misunderstanding - of the text that he has himself. Furthermore, he should seek to win as wide an audience for the translation as possible, expanding the circle of readers beyond that group who will read the story in any case because they already are familiar with Chinese history and culture. Thus, although some of my notes may appear superfluous to some readers, I trust there will be others who find them useful.

37. It was my privilege to meet the Yangs while attending the centennial celebration of Lu Xun's birth in the summer of 198I. During the second of my two weeks in China, Mrs. Yang accompanied a group of foreign guests on a visit to Lu Xun's hometown. Call to Arms is the Yangs' translation of Nahan, the title I translate as Cheering from the Sidelines. 